\title{
Strengthening Tacit and Explicit Multicultural Knowledge in Elementary Schools
}

\author{
Daniel Dike1,a, Lusila Parida1,b, Thomas Joni Verawanto Aristo 1,c Muhammad Nur Wangid 1,d \\ ${ }^{1}$ STKIP Persada Khatulistiwa Sintang Indonesia, ${ }^{1, d}$ State University of Yogyakarta \\ a dikedanieltukan@gmail.com; b30101986lp@gmail.com; c thomaspaoh@gmail.com; dm_nurwangid@uny.ac.id \\ ${ }^{*}$ Corresponding Author \\ Whatsapp number: [085240048755]
}

How to Cite : Dike, D., Parida, L., Aristo, T., J., V., Wangid, M., N. (2020). Strengthening Tacit and Explicit Multicultural Knowledge in Elementary Schools. International Journal for Educational and Vocational Studies, 2 (1), 25-31. DOI: https://doi.org/10.29103/ijevs.v2i1.1884

\section{ARTICLE HISTORY}

Received:17 October 2019

Revised: 22 December 2019

Accepted: 26 January 2020

\section{KEYWORDS}

\section{Implicit;}

Tacit Knowledge;

Multicultural Epicenter;

\begin{abstract}
This study aims to develop tacit and explicit knowledge to strengthen the values and attitudes of multicultural education in elementary schools. This research method was used a case study design, and it held at the Elementary schools in Sintang regency, West Kalimantan. The Findings showed the similarity of understanding among school members to the concept of multicultural educational Catholic schools, public schools, and Islamic schools. Conceptually the understanding of multicultural education has not been formulated in an explicit multicultural idea. However, the awareness of multicultural values and attitudes has been patterned through an attitude of appreciation for diversity, respect for diversity, living brotherhood and unity rooted in the religious values of Christianity, Islam and the local traditions of Dayak's and Malay. Strengthening explicit and tacit knowledge in the process of education and learning to improve the pedagogy of equality and social justice at the elementary school level. This effort can be realized if classrooms are innovated into a multicultural epicenter. It is recommended that the process of socialization, internalization, and the combination of learning approaches and the use of various media, supplements, and multicultural learning modules. Those can be used to develop tacit and explicit knowledge so that multicultural education in elementary schools can be realized and rooted in the education process as one of the characteristics of elementary school education in Indonesia.
\end{abstract}

This is an open access article under the CC-BY-SA license.

\section{INTRODUCTION}

Multicultural education is not limited to dimensions of cultural differences but includes many aspects of social access and community education. Socio-economic inequality, discriminatory behavior, ethnic prejudice, discrimination in color, gender, majority-minority issues, indigenous and non-indigenous issues and lack of access to students with special needs are an inseparable part of multicultural education which until now is still a problem in the midst multicultural society. Therefore, critical multiculturalists claim that in the level of concepts and praxis multiculturalism has not been proven to be able to fully overcome various obstacles for the realization of equality and social justice in the midst of citizens and nations (Alismail, 2016; Sharma, 2016). It is recognized that there are many fall short, and the inequality social economy, culture, access to social services including gaps quality and access in the field of education between urban and rural area as well as remote and border areas in the eastern sector of the province of West Kalimantan. Because of that, the government is trying to equalize not only the equal distribution of access but also the even distribution of quality education in all regions. This has been proven since 2015, the Smart Indonesia Program (PIP) has helped more than 17.9 million school-age children who come from poor and vulnerable poor families throughout Indonesia (Daniel Dike., 2017; Niken Widya Yunita, 2017). However, the priority programs of the government through Ministry of Education and Cultural was not fully targeted and precise quality. Access and education services, such as the placement of teachers on the front lines, areas outlying and remote, the implementation of the teaching profession program with nation standard was not able to reach teachers and prospective teachers in the area. Although there were attempts to transparency and justice as through 
civil service test was online but the access gap quality of education centers and regions still continue to become problems in the social reality of education in Indonesia.

Darraz Abdullah explained that the research Maarif Institute found that the process of entry of radicalism in schools is done through three way, there are that alumni, teachers and school policy (Rony Sitanggang, 2018). Teacher can be an actor of radicalization because it is affiliated with radical groups outside of school. The teacher did not only focus teach religious subjects but also the other subjects and it could be a radical ideologies, this kind of activities are happen at the learning activities and also at the extracurricular activities (Rony Sitanggang, 2018). That situation growth up and developed because the unawareness understanding of tacit and explicit multicultural, it is also supported by the absence of a policy that specifically to protect the school from penetrating understanding and radical movements in schools although some people doubting the magnitude of the influence of radicalism that infiltrate the world of school and college (Nuraki Aziz, 2018).

\section{METHODS}

The research method used a qualitative method because explorative portraying the reality of multicultural praxix in schools in depth, detail, and complete in order to obtain a complete picture of multicultural education in elementary schools.

\subsection{Types of research}

This research used case study research. Case study means of emic research because it present the views of the subjects studied with their situational uniqueness. Is showed comprehensive description match what is experienced in daily life (everyday real life), especially the complexity and interaction of her with the background conditions of the back (Stake, 2005), related to the praxis of multicultural education in primary schools Sintang.

\subsection{Time and Place of Research}

This research was conducted in Sintang, West Kalimantan Province precisely in elementary schools that exist in the town of Sintang. School in the town of Sintang fairly represent and reflect the ethnic and religious picture and representative characteristics of a multicultural region of West Kalimantan East sector. The selection of research locations uses a purposive sampling area technique. The time of the study was conducted for one year from October 2016 to March 2017.

\subsection{Research Targets and Subjects}

Research subjects used in this study determined by purposive sampling are the headmaster, teachers, students, parents, leaders of the foundation of the three schools were chosen in consideration of the suitability of ethnicity and religion. Data subjects were 28 participants with details of 3 school principals, 10 teachers, 6 parents, 6 students and 3 figures.

\subsection{Procedure}

Case study research proceeds by specifically examining the praxis of multicultural education in primary schools related to understanding, values and multicultural attitudes of school citizens in terms of why and how about multicultural understanding and attitudes of school residents in Catholic elementary, public elementary and Islamic elementary schools Integrated so as to achieve a detailed and in-depth description (Ary, D., Jacobs, L.C., \& Sorensen, 2010) of a deep understanding of the case (multicultural praxis).

\subsection{Data, Instrument, and Data Collection Techniques}

Data collection technique used through in-depth interviews related to understanding, values and multicultural attitudes of school residents, including school principals, teachers, students, parents and educational figures or community members representing schools with a Catholic, state and Islamic vision. Qualitative design used in this research combined various data both observation, interviews and in-depth document elaborating social phenomena and multicultural context data sources are valid and credible (Jansen, 2010). The observation center was the activities and activities of teachers and students in the learning process at school. The process and dynamics were observed, recorded and then compiled as findings and then compared through triangulation techniques.

\subsection{Data analysis technique}

All data obtained from interviews have contributed directly or indirectly to various sources and perspectives so that the triangulation process ultimately ensures the accuracy, accuracy and reliability of the data (Ary, D., Jacobs, L.C., \& Sorensen, 2010; Lee, 2008). The unit of analysis was the group of teachers and students, parents and figures about multicultural understanding, values and attitudes after that the data were compared and drawn the conclusions were inductively carried out (Baxter \& Jack, 2008)

\section{RESULTS AND DISCUSSION}

\subsection{Multicultural Understanding: Tacit and Explicit Knowledge}

Knowledge, understanding, awareness of values and multicultural characteristics of the citizens of Panca Setya Catholic Elementary School, SD Negeri 5 and Integrated Islamic Elementary School Buah Hati Sintang are closely related and rooted in personal and social experiences in the environment of each school and community as well as culture and also religious belief by each school citizen. This can be seen from the expression conveyed by one of the homeroom teachers in Panca Setya Catholic Elementary School that the concept or 
understanding of multicultural education that they understand was closely related to culture, "Multi means a lot, culture means culture, and so multiculturalism can mean education that emphasizes the diversity of cultures that exist in society." The same thing was also stated by the principal of SD Negeri 5 he said that, for him multicultural education is education related to managing pluralism that ends in the final goal is to strengthen and maintain brotherhood among each other. He stated thus: "The diversity of this state school is clear, teachers and students are including many ethnicities; there are Malays, Javanese, Dayak, Batak, Flores all living in one voice and harmony. Like me, who is from Java, Catholic, does not feel as a migrant, or a minority but feels as a local in Sintang, and has become a native Sintang."

From these two understandings, it is clear that the knowledge about multicultural education understood by teachers is very closely related to the basic elements and concepts related to cultural diversity both in the physical sense and geographic dimensions of the origin, language, ethnicity, religion adopted by school members. That is, what is called diversity is cultural diversity. Diversity also touches on personal and group identities as Javanese, Dayak or Malay people or ethnic groups. It is clear here that diversity always has a sense of respect for the individual and social rights and identities of where it originates and lives. There is also an implicit understanding that is built from the teacher's experience, for example, the term Dayak always connotes a particular community's identity. In common sense, for example, Dayak is always connoted as a Christian while Malay is connoted to Islam, while a slug is always connoted by Tingohoa even though it is not entirely true and correct. Such general understanding is born from the social context of schools and communities that have very diverse and unique colors of multicultural experience related to ethnicity and religion.

The picture of multicultural understanding actually begins or is well formed through the multicultural school social environment. Multicultural environments such as in Catholic schools are developed and empowered in the learning process in the classroom or school. This was seen in the apple program with the elementary, junior high and vocational school communities in the third week. Also there is a mass program in early school involving elementary and junior high Setya Panca conducted in the central courtyard of the school. The social reality and multicultural environment (multicultural ecology) provide opportunities to stimulate the birth of multicultural implicit understanding. The social environment of the school which is quite homogeneous in both Catholic schools, public schools and Islamic schools actually has the same pattern in shaping implicit understanding of teachers and students. The different is the emphasis on specific educational practices and visions especially for Islamic and Catholic education, because there are special policies such as religious teaching, or teacher recruitment, prayer practices and special traditions that are the main characteristics of special schools.

An explicit understanding of multiculturalism can be found from teachers' experience at SDN 5. Islamic religious teachers for example revealed that, "I know that multiculturalism, for example Islam is Malay, the Dayak is Christian." Spontaneous answers from Islamic religious teachers illustrate the understanding that the diversity of citizens the school is related first of all to cultural and religious identities. Ethnic and religious differences in teacher experience are the two most prominent realities or the most easily exemplified when discussing differences in school and society because that is the most dominant identity seen and felt. Ethnic and religious issues become explicit and implicit conversations among teachers, whether within their groups or beyond ethnicity and religion.

Ethnic and religious realities are two elements that give a very strong impression in the understanding of school residents because these two things talk about individual identity and group identity. In Sintang's social cultural awareness, ethnic identity also explains religious identity. This is very visible from the spontaneous feelings and thoughts in the understanding of most citizens including school residents with the phrase "Dayaks are Christians, Malay is Islam, China is the eye of Sipit." From this description of introduction it can be related that the construction of multicultural education understanding of school residents is also related to concepts regarding individual identity, group identity, ethnic identity and religious identity. How school people understand the differences in the identity of individuals and groups is very dependent on the environment, the thoughts that live in the family and the school environment of Catholic, Christian or Islamic school. The identity of ethnic and religious groups in the experience of Panca Setya 1 Catholic school residents was seen with a positive and religious perspective. This is revealed in the words of the principal and teachers about the difference in identity as a given reality, a gift from the creator that should be received and grateful together. The gift is a natural human calling and it is humane to complement and perfect each other towards the fullness of life as a human being created by God or the image of God.

Ethic and religious multicultural understanding and appreciation that was built among SD Panca Setya 1 teachers are interpreted to be the same or similar to the multicultural appreciation or awareness of school residents in the Buah Hati Sintang Integrated Islamic Elementary School. This was revealed in the principal's belief that, "Pluralism is the will of Allah SWT, which encourages all humans to build an Islamic brotherhood that is rahmatan lil alamin." This means that Islam comes for everyone and brings everyone to Allah, because Islam is basically a religion of peace. That was clear that the characteristics of multicultural conceived or built at environmental school characterized by religion basically and religiously oriented because of the value of 
spirituality lived citizen of school personal, communal and are institutionally appropriate school identity as SD Buah Hati Islam Sintang, which is used the values Islamic developed in all educational processes. The learning environment and activities that are strongly colored by Islamic culture and traditions strongly support the strong implicit understanding of multicultural education that is rooted or grounded in Islamic teaching and belief.

The concept and understanding that grew in the two private schools with religious characteristics turned out to be similar to the understanding and belief of the citizens of public schools. Multicultural understanding that is built by teachers in state schools is to see differences or to be bored as a characteristic of identity to Indonesia. Indonesianness is truly experienced in the environment and the community school community because all ethnicities, religions both in terms of students and teachers are quite evenly distributed. These situations and conditions of diversity help shape and strengthen the implicit and explicit multicultural understanding that he and the teachers and students have.

Implicit and explicit understanding of the diversity that is similar to school residents in the three schools, Islam, Catholicism and the country according to Ki Hadjar Dewantara was built and lived by the same social and environmental context so as to construct the understanding and values of Indonesian society that is plural but has a "kesatuan laku dan lakon" (Majelis Luhur Persatuan Taman Siswa, 2013a). The understanding of diversity that is explored from the experience of school residents in Catholic schools, Islamic schools and public schools reflects a belief that Banks calls a set of believe (Banks \& Banks, 2010). The diversity of cultures, ethnicities and religions are rooted in Indonesian society as a lifestyle (way of life) that already integrated in reality a social experience as a (mosaic) and cultural diversity actually tampered with the colonial system. The colonial system has created social classes, social classes built ethnic discrimantion, skin colour (vreenide oosterlingen) wich paces certain groups into superior classes above others (Majelis Luhur Persatuan Taman Siswa, 2013b). In the aspect of multicultural understanding the level of knowledge of school residents shows that their knowledge and understanding is in the implicit category of knowledge. What knowledge is implicit, such a "secretly, quietly know, or can know more than can be said" (Davies, 2015).

\subsection{Awareness of Multicultural Values and Attitudes}

Expressions of values and attitudes of diversity in Catholic primary schools that are dominant by ethnic and cultural students of Dayak are historically and culturally derived from the philosophy and cultural awareness of the Dayak Desa community as in the following "kura sekerubang aji separu, kata sama tutur sutik." It means one togetherness, or one group, one boat, one word, one voice, one shared vision. The value of togetherness that is lived not only explains together as a group of groups but reflects the quality of relationships and physical and spiritual unity (physical and spiritual). This is a strong unity; brotherhood and togetherness in Dayak culture which is reflected in the Huma Betang tradition (Betang house) and these cultural values are in line with Christian values. The Betang House tradition inherits the values of virtue and goodness in the togetherness of the extended family that inhabits the Betang house as a family unit. Diversity is the essence of multiculturalism so that in the process of living together there cannot be room for feelings, ways of thinking or prejudices or strotypes let alone attitudes of discrimination. In the understanding of the Dayak Desa tribe, it is likened to the philosophy of sugar cane "bisik tungkung adai ruas, bisik laik adai lapat." It means, the cane has a segment that divides the part of the leaf, but the part of the leaf is a unit that does not differentiate or separate. In the Dayak ideas or philosophies of plurality villages or differences, it looks like a stick that has segments, there is a boundary for each segment, with a small large size, or a short length, but the segments cannot be separated from the unity that forms the sticks. Leaves can have the same essence and meaning, are equal and become an important or essential part of the nature, functions and benefits of the tree as a physical entity and the same meaning.

The concept of difference in the Dayak Desa philosophy is the same as being dominant in the community in SD Negeri and SD IT where the majority of students are ethnic Malays. The Malay philosophy in the phrase is "sama mantau sama ninyau, sak jom berebot begili." It means, both look at, review which parts belong to them, so that later they will not fight over to recognize rights as their own rights. This expression means that in Malay culture every person is required for mutual respect, not mutually damaging or usurping the rights of others. Malay culture requires that everyone care for one another and care for each other so that all the interests and rights of others are protected and protected, that is the essence of living together. In the awareness of the Malay community the existence of individuals is an element that forms a group or community unit. Diversity or differences in society itself will not exist if a person's existence is not recognized or valued. Differences brought by each individual or group are important and essential to be recognized and treated. The message for education is the diversity of ethnicity, religion, culture, economy, politics; ideology in society is essential, must exist and be respected by every individual in the community. The hallmark of the Catholic school as it takes place in SD PS 1 is an effort to gain knowledge and instill gradual values about the world, life and people who are illuminated by faith with the qualities of love, brotherhood, faith in God, the spirit of love, and the values of social values, morality and intellect. The quality of this faith is based on the 
conception of Catholic schools that emphasize education which includes the ability to have a high commitment to history and tradition, to appreciate reason and longing for truth, serve global brotherhood and solidarity and trust humans as spiritual beings (Mbula, 2017). These capability qualities are pursued in educational programs that are integrated with the curriculum, especially in extra-curricular activities or monthly, semester or annual programs such as retreats, monthly mass, arts and culture, scouting, joint Christmas, pre-Easter activities and Easter activities together with other spiritual formation. These values and attitudes are not learned and grown with specific curriculums but are developed through school extracurricular programs and various spiritual, spiritual and personality development programs to strengthen the values that have been expressed in the national education and curriculum system.

It can be said that the level or multicultural level practiced at SDN 5 according to the author's analysis is in line with the concept of Bhikhu Parek and can be categorized as a synthesis model between sub-cultural diversity and communal diversity (Parekh, 2008). This means that in subcultural diversity a shared culture is emphasized that is shared by Indonesian culture and it is hoped that this national culture is wide open to all groups, having Unity in Diversity and not shifting from one another. This multicultural awareness enables people with different cultural backgrounds to be able to maintain their uniqueness by the existence of religious, ethnic and cultural differences so that they can live together well and healthily (Liliweri, 2007).

In the diversity of sub-cultures each community has a dominant group value system and seeks to open space for lifestyle differences that exist in it. For example, at schools national awards and tolerances are held so that each religious group can celebrate their special religious celebrations such as joint Christmas or joint Halal Bihalal. Togetherness or brotherhood and community environment at SDN 5 Sintang does not reflect or present an alternative culture but tries to make existing cultures become more plural and develop in line with the social and cultural interactions of the Sintang community. On the other hand it also shows the face or pattern of communal diversity meaning that school people realize themselves as different community groups; there are Malay, Javanese, Dayak, Bugis, Padang, Timor, Flores, Batak, Christian Islam, Catholicism, Buddhism, Confucianism, Hindu. The multicultural pattern in SD IT is an expression of a combination of Malay and Javanese culture (mixed culture) but patterned by a strong Islamic spirit. The specificity of the multicultural praxis dimension in SD IT lies in the special characteristics of the school community which is more homogeneous in religion because its population base is the majority ethnic Malay and Javanese Muslim.

SD IT Buah Hati Sintang uses two curricula namely the national curriculum and the Islamic curriculum with this basic vision namely Gave birth to an intelligent, skilled and competitive generation of Rabbani through the integration of curriculum and methodology as well as an integrated Islamic education program that includes the formation of knowledge, inculcation of Islamic values and motivation for charity. The application of these two curriculums characterizes the different multicultural patterns in SD IT with other primary schools such as SDN 5 and SD Panca Setya 1 which are both religiously characterized or characterized. In the learning process at SD IT Buah Hati Sintang, Islamic knowledge, values and attitudes are integrated in the whole process of learning and personal or group guidance carried out by educators whose notes are given the meaning and meaning of more than just the teacher but given the role of religious educator, they are ustadz and ustadzah. This concept was born because in the process of education at SD IT Buah Hati Sintang, there was an integration of the education system and the value system that had the ultimate goal of creating or giving birth to a generation of Rabbani, such as the future generation with the qualities of knowledge, values and attitudes inheriting the qualities of God and the apostles. This is clearly illustrated from the integration of the national curriculum and the Islamic curriculum in the education process at SD IT Buah Hati Sintang.

The consequence of the integration of the national curriculum and the Islamic curriculum in learning is that a process called learning Islamization means that all content and learning processes are packaged according to values, principles, and fundamentals of Islamic teachings with the main source of the Koran and the hadith while still guided by national education policy for one main goal or estuary, they are the formation of Islamic student characters and the ideals of the realization of the rabbani generation. Because the demands were on the basic references and principles of Islamic values, all components and governance institutions are all characterized by Islam. This ultimately affects the recruitment process and the qualifications of teacher and employee personnel must have an Islamic background or belief.

The further impact is on the aspects of governance and human resources being limited or "closed" only to certain communities based on common religious beliefs. That wasan opportunities in the acceptance of teachers and employees, students of course only accept people or students from the Muslim community according to the specific vision, mission, and special goals of the school. The effect is institutionally both at the level of governance management and the actors involved in the governance system are intended for those who have the same beliefs. In other words, outside of Islam, do not get the opportunity or closed the opportunity to become a supervisor or educator. The competence or professional capacity of the teacher or employee needed is also in accordance with the curriculum and concept of Islamic education. This is a special feature possessed by SD IT and is a privilege protected by law. In a multicultural perspective such special traits must be maintained and 
respected as special features of Islamic schools in the context of Indonesia's diversity with special contributions in shaping and building human resources with special character capacities as Indonesian citizens with insight, Islamic values and attitudes according to the first characteristics of the first precepts of Pancasila, that was "the God of the Almighty. Every citizen, group and diverse community still recognizes and believes in their respective religions with a citizenship orientation and Pancasila character. In the educational process the development of aspects of knowledge and values of Pancasila must be dynamic, meaning that there is wide open space for interpretation and interpretation without conflicting with the values of universal morality. The educational philosophy that should be developed in the Indonesian education process is that Pancasila is established as a foundation and guide in the process of national education reform and renewal (Siswoyo, 2014).

\subsection{Efforts to Strengthen Multicultural Knowledge and Attitudes}

Increased understanding, awareness of values and multicultural attitudes can be done through four strategies namely socialization, externalization, combination, and internalization. Multicultural socialization steps can be taken through empathy with other people and their environment. Subjective exchanges between individuals in the classroom or school environment will help students acquire and enhance explicit knowledge by removing prejudiced (Nonoka, 2005). In the classroom and school environment students can gather tacit knowledge sharing about their world. The teacher's role in this process is to improvise dynamic interactions between individuals and groups in the process of social interaction. The goal is that the learning process can accumulate to form students' knowledge and insights into intelligent and inspiring individuals. Improvisation of multicultural knowledge, values and attitudes involves all subjects and actors with the support of elements of learning methods and media such as observations, presentations, reports, discussions, and internalization of multicultural values through learning media. This activity is carried out collaboratively with the teacher or team of teachers.

\section{CONCLUSION}

Strengthen the understanding and knowledge of multicultural are important because according to Nonoka knowledge based on the assumption that humans are not the only part that was not perfect from the processing of information but it is the existence of which has the potential to grow together through the process of knowledge creation (Nonoka 2005 , p. 378). In the theory of knowledge Nonoka, classes were the epicenter or focal point of knowledge creation for classroom as a "place" (場, ba) where the students go beyond subjectivity and the process of human interaction through four strategies that learning the socialization, externalization, combination, and internalization. Subjective exchanges between individuals in the classroom or school environment to help students increase explicit knowledge by removing prejudiced prejudices (Nonoka, 2005, p. 383). In the classroom and school environment students can gather tacit knowledge sharing about their world. The teacher's role in this process is to improvise dynamic interactions between individuals and groups in the process of social interaction. The goal is that the learning process can accumulate to form students' knowledge and insights into intelligent and inspiring individuals.

Strengthening of tacit and explicit knowledge of students in the learning process required the improvisation of the development knowledge, values and attitudes of multicultural that involves all subject good principals, teachers, students, the parents, education authorities and the community through innovation and support methods and media of learning such as multiply activities observations, presentations, reports, discussions and internalization of multicultural values through learning experiences and media such as films, cultural week activities, cultural camps, local and national cultural and dance performances. Improve the collaboration of the teacher or teacher team in facilitating students and enlivening the classroom as a multicultural center or epicenter in each school or across schools. Pay attention and seriously developing aspects of student diversity, social background, conditions of disability aiming at fostering a level of explicit understanding, as well as awareness of values and multicultural attitudes in supporting the development of multicultural competencies of school members. Strengthening cultural literacy, information literacy and technology to broaden and deepen knowledge, values, attitudes and instincts of respect for diversity and social, economic, political, ethnic and religious differences that often trigger conflict in Indonesia.

\section{REFERENCES}

Alismail, H. A. (2016). Multicultural education: Teacher's perceptions and preparation. Journal of Education and Practice, 7(11), 139-146. Retrieved from http://iiste.org/Journals/index.php/JEP/article/view/2 9857

Ary, D., Jacobs, L.C., \& Sorensen, C. (2010). Introduction to research in education (eighth). Belmont: wadsworth Cengage Learning.

Banks, J. A., \& Banks, C. A. M. (2010). Multicultural education: Issues and perspectives (Wiley). New York, N.Y.: Macmillan.

Baxter, P., \& Jack, S. (2008). Qualitative case study methodology: Study design and implementation for novice researchers. The Qualitative Report, 13(4), 544-559. https://doi.org/citeulike-article-id:6670384

Daniel Dike. (2017). Pendidikan multikultural sekolah 
dasar di wilayah 3T. Jurnal Pendidikan Dasar PerKhasa, 3(1), 277-287. Retrieved from http://jurnal.stkippersada.ac.id/jurnal/index.php/inde $\mathrm{x}$

Davies, M. (2015). Knowledge (explicit, implicit and tacit): Philosophical aspects. In International Encyclopedia of the Social \& Behavioral Sciences: Second Edition (Second, pp. 74-90). Oxford: Elsevier. https://doi.org/10.1016/B978-0-08-097086-8.63043-X

Jansen, H. (2010). The logic of qualitative survey research and its position in the field of social research methods. Forum Qualitative Sozialforschung/ Forum: Qualitative Social Research, 11(2). https://doi.org/10.17169/FQS-11.2.1450

Lee, J. (2008). Multicultural Education in South Korean Public Elementary Schools: An Analysis of Teachers' Experiences and Perspectives and School Curriculum, 9.

Liliweri, A. M. . (2007). Makna budaya dalam Komunikasi antar budaya (ke-2). Yogyakarta: Lkis Yogyakarta.

Majelis Luhur Persatuan Taman Siswa. (2013a). Kihadjar Dewantara: Pemikiran, konsepsi, keteladanan, sikap merdeka (II). Yogyakarta: Universitas Sarjanawiyata Tamansiswa (UST Press).

Majelis Luhur Persatuan Taman Siswa. (2013b). KIhajar Dewantara: Pemikiran, konsepsi,keteloadanan, sikap merdeka (II). Yogyakarta: Universitas Sarjanawiyata Tamansiswa (UST Press).

Mbula, V. D. (2017). Mendisaian kurikulum integrasi sekolah dalam dinamika perkembangan kurikulum nasional. In Rosalia Emmy (Ed.), Lembaga Pendidikan katolik dalam konteks Indonesia (ke 5, pp. 91-114). Yogyakarta: PT Kanisius.

Niken Widya Yunita. (2017, August). Jurus mendikbud percepat pendidikan yang merata dan berkualitas. DetikNews. $\quad$ Retrieved from https:/news.detik.com/berita/d-3603275/jurus-mendi kbud-percepat-pendidikan-yang-merata-dan-berkuali tas

Nonoka, I. (2005). Managing organizational knowledge theoretical and methodological foundations, great minds in management: The process of theory and development. London: Oxford, Oxford University Press.

Nuraki Aziz. (2018, June 5). Temuan BNPT tentang paparan radikalisme di sejumlah universitas dipertanyakan. $B B C$ Indonesia. Retrieved from https://www.bbc.com/indonesia/indonesia-44357353

Parekh, B. (2008). Rethinking Multikulturalism: Keberagaman budaya dan teori politik (Terjemahan). Yogyakarta: PT Kanisius.

Rony Sitanggang. (2018, January 26). Riset maarif institute, waspadai 3 pintu radikalisasi di sekolah. KBR, Jakarta. Retrieved from https://kbr.id/nasional/01-2018/riset_maarif_institute html

waspadai_3_pintu_radikalisasi_di_sekolah/94719.

Sharma, S. (2016). Multicultural Education: Teachers' Perceptions And Preparation. Journal of College Teaching \& Learning (TLC), 7(11), 139-146. Retrieved from http://journals.cluteonline.com/index.php/TLC/article/ view/1825

Siswoyo, D. (2014). Urgency of the national education philospphy in rebuilding the national identity (pp. 104-111). Yogyakarta: e-print uny. Retrieved from http://eprints.uny.ac.id/view/subjects/ICFIE2014.htm 1

Stake, R. E. (2005). Qualitative case studies. In N. K. Denzin \& Y. . Lincoln (Eds.), The Sage Handbook of Qualitative Research (pp. 443-466). Thousand Oaks, CA.: Sage Publications Ltd.

Wilson, M. B., \& Kumar, T. (2017). Long ago and far away: Preservice teachers' (mis)conceptions surrounding racism. International Journal of Multicultural Education, $19(2), \quad 182-198$. https://doi.org/10.18251/ijme.v19i2.1346 